\title{
THE ROLE OF MASTER-BUILDER IN DEVELOPMENT OF TRADITIONAL OHRID HOUSE
}

\author{
A B S T R A C T
}

Master-builder of traditional Ohrid house had important role for the origin and development of some particular elements of construction and finalisation, which are typical solutions that create a specific expression of the Ohrid residential architecture.

Formation and development of the traditional Ohrid house, as a regional variant of the Ottoman type of urban house, with specific indigenous characteristics that are specifically related to the spatial plan and the structural details, was created by masterbuilders of Ohrid, Struga and Debar. Their contribution in the stylistic unification of the Ottoman residential architecture, as well as in finding innovative and specific solutions, is very significant. 


\section{INTRODUCTION}

Traditional architecture, in general, is a result of the work of anonymous builders. In the case of traditional architecture in the town of Ohrid, master builders demonstrated distinct skills and knowledge that gave specific, autochthonous expression of buildings from this region. The roots of such architectural operation can be found in geographic and climatic characteristics of the region, as well as in existing social and historical conditions which have been favourable for appearance of traditional Ohrid house.

Ohrid belongs to the group of rare Balkan cities which have existed continuously having a rich history since the prehistoric (neolithic) period, until today. The presence and practice of different building traditions is a result of the geographic location of this region as a crossroad of trade and cultural links between the East and the West. The rich history of architecture of the town of Ohrid certainly offered inspiring and meaningful lessons to the builders. The created symbiosis of building techniques from different periods in one place enabled continuity of building traditions. At the same time it had influence in adapting the well-known architectural constants to the specific and newly created needs and demands of the population, as well as to particular conditions of the location, resulting in the formation of the specific expression of the traditional Ohrid house.

\section{Traditional Ohrid house - a specific regional architectural expression}

There are several open issues, scientific discussion and opposing viewpoints about the question of the origin of a typical house of the Balkans and that of the Eastern Mediterranean area. Thus, Turkish researchers believe that similarities between the Balkan and Anatolian types of houses are a direct consequence of the Ottoman influence, ${ }^{1}$ while the researchers from the Balkan countries usually look for the origin of the Balkan house in the Byzantine palace and further in the medieval feudal tower. (Fig.1a and 1b) ${ }^{2}$ A great similarity can be found between the external shape of the feudal tower (Fig.1b) and the houses of the $17^{\text {th }}$ and $18^{\text {th }}$ century from the territory of Macedonia, Albania and Greece (Fig. 1c - 1f.). ${ }^{3}$ Regarding the applied building techniques, the Balkan authors believe that material and technological base of a traditional Balkan house is found in the Byzantine masonry techniques, as well as in the Slavic techniques of building with wood. Besides, a great similarity can be found between the houses from Greece (Mistra, Kastoria, Veria and Trikeri) and those from Galičnik in Macedonia (Fig.1.e and 1.f), where we can search for the origin of the Macedonian rural house. ${ }^{4}$ 



Figure 1. Origins of traditional house in Macedonia: a) The stone consoles of the Byzantine palace in Mistra, Greece; b) 14th century drawing showing medieval fortress and wooden bay windows of the feudal towers; c) 17th century House in Trikeri, Greece; d) 18th century house - Kastoria, Greece; e) 17th century rural house in the vilage of Galičik; f) $18^{\text {th }}$ century rural house in the vilage of Galičnik.

(source: a. A. Orlandos, Anthologhia Hellenikěs Architektonikěs. Athens, 1981.; b. Хаџиева Алексиевска, Мерки, Антропоморфност и модуларни пропориии кај старата македонска кука, Скопје: Студентски збор, 1985.); с, е, f. С. Томоски, Македонска народна архитектура, Скопје: Технички Факултет -

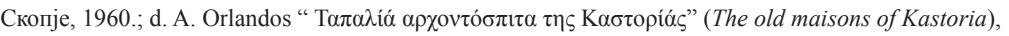
Archives of the Bizantine Monuments of Greece, v. IV, Athens, 1938.)

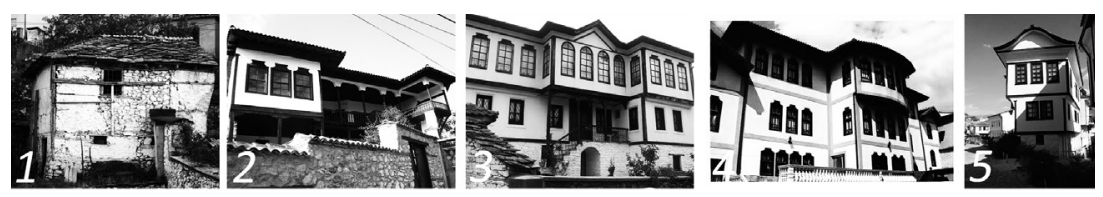

Figure 2. The spatial development of the Macedonian town house: 1) Štip, one-storey house; 2) Veles, two-storey house; 3) Wide Kruševo house; 4) Wide and simetrical Debar house; 5) Tall Ohrid house. (source: Authors)


Figure 3. Tipical exprecion of traditional Ohrid house: a) The Filevci house; b) The House of Kanevče family; c) The Robevci house and part of the Uranija house. (source: Authors) 
As a result of the Ottoman domination in the Balkan region, typological analysis of the spatial organization of the $19^{\text {th }}$ century urban house in Macedonia and those of the neighbouring countries pointed out the presence of different basic types throughout the territory. The only exception are the very numerous "L" type houses in Macedonia, which was the most frequently used house type in Ohrid's secular architecture, but which is either rare or not present in other parts of the Empire. ${ }^{5}$ The type resulted from the urban milieu of Ohrid and different conditions of the lot, the position to the neighbours, etc. The features of this type are result of different shapes and dispositions of the balcony ( $\check{c} a r d a k$ ) and the porch in the different storeys. Another typical solution for Ohrid residential architecture is the placement of the so called winter kitchen on the mezzanine level, ${ }^{6}$ but its most specific feature is its development through three or four storeys.

The spatial development of the Macedonian house starts with the one-storey house from Štip, through the Veles two-storey house till the tall Ohrid house, having two-storey porches, and winter and summer apartment on separate floors (Fig.2). The Ohrid house is often a building built between other houses, which grow in height, unlike the Veles and Kruševo houses, which grow in width. On the other hand, the Kruševo and Debar houses are mostly symmetric, while the Ohrid types are mostly asymmetrical, having a very dynamic silhouette.

\section{Social circumstances of occurrence of traditional Ohrid house}

According to the notes from the travel writers, the Ohrid house appeared in the $17^{\text {th }}$ century. These houses were described as beautiful, masterfully built, having porches and balconies. ${ }^{7}$ In the $18^{\text {th }}$ century, the space plan and the constructional details of the elements evolved and developed, starting to acquire their indigenous features. In the early $19^{\text {th }}$ century, development and the increase of artisan and merchant class influenced the increment in the number of Christian houses in Ohrid. In this period there is a reduction in size of plots, while the houses became built-in and tall.

During their travels to Europe, Ohrid traders got familiar with the current styles in architecture (baroque, classicism). Their latter requirements for houses after the European style have contributed to the newly formed symbiosis between the Ottoman and the Western European architectural style. The culmination of the residential architecture in Macedonia was in the period from 1830 to 1880 , so-called "the period of renaissance in Macedonia". ${ }^{8}$ Some of the most valuable examples of these houses are in the town of Ohrid (Fig.3). 
Travel writers of the time speak of a clear division of the town into the Christian part, or the town on a hill, and the Muslim part, i.e. the eastern part of the town near the lake. ${ }^{9}$ Accordingly, two types of houses that were very different from each other regarding the plot size, shape and size of the base, spatial organization, form, number of storyes and the openness of the facade were built by using the same, combined constructive system (massive and timber-frame system, so-called bondruk).

While the Muslim house did not differ from those from other parts of Macedonia or the wider region, being always on a huge and flat plot, consisted of a ground floor and a first floor, with a large number of auxiliary rooms in the courtyard that was surrounded by high walls, and practising a symmetrical scheme, the Christian house rejected all attempts to be schematic. Houses of the Christian population usually had an irregular plan as a result of efforts to make better use of the location. A particular architectural expression of the house included a specific treatment of the yard, which became a part of the interior of the house, while the ground floor level of the house was closed towards the street. In this way, the cellar and the summer kitchen remained in the yard, and the winter residence was on the mezzanine level. The floors of the summer residence were opened to the street, towards the sun and the Ohrid Lake.

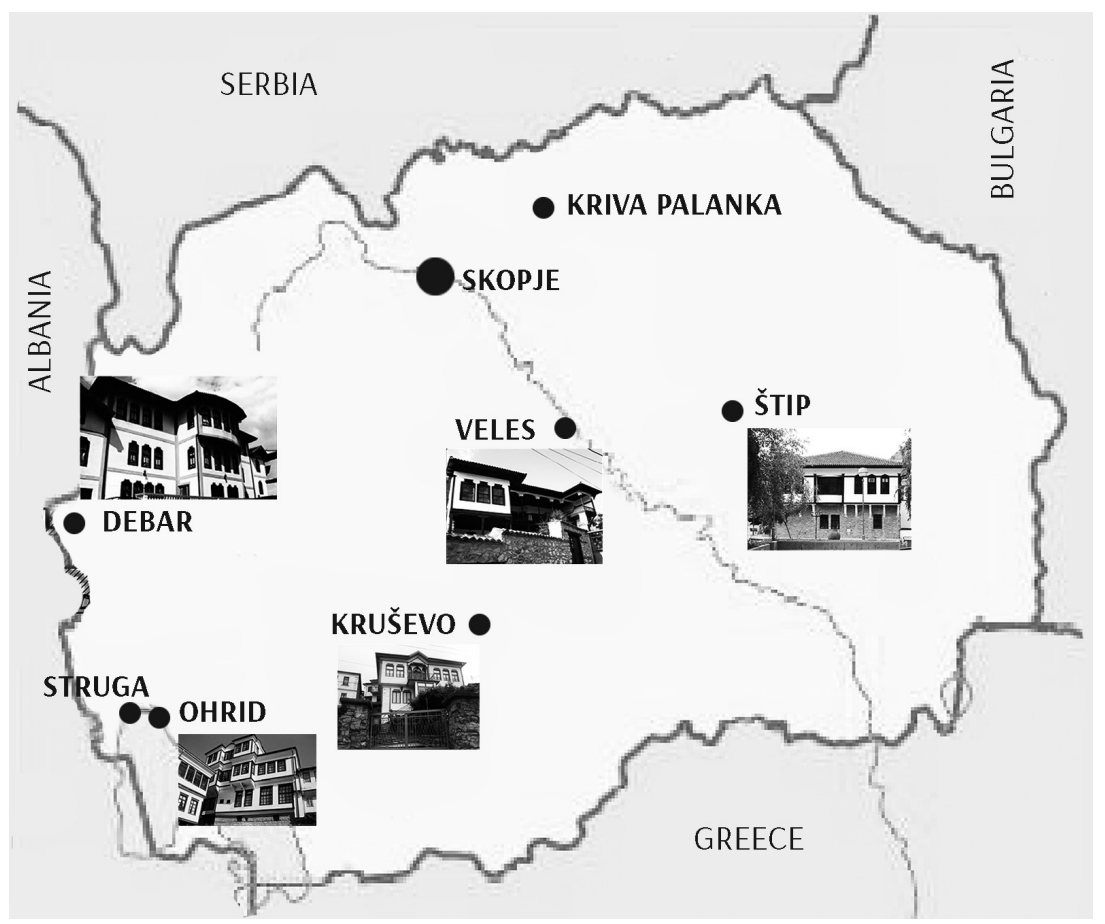

Figure 4. The most famous building centars in Macedonia (source: Authors) 
MASTER BUILDERS

\section{Position of the master builder in the hierarchy of ottoman architecture}

Master builders had a specific and particular role in the process of creation of the Ottoman residential architecture. In the Ottoman urban culture, there was a clear distinction between the architect and the master builder, yet together they were both responsible for everything that has been built on the territory of the Ottoman Empire. The architect, unlike the builder, was educated in the socalled has schools. However, since the has schools were much more oriented towards engineering than architecture, the work of an architect was the work of a technician involved in the design of military and hydraulic devices. The architects followed the Empire's style established in the second half of the $16^{\text {th }}$ century by mimar Sinan, the major imperial architect of the time until the end of $18^{\text {th }}$ century when the Empire has opened towards the western European influences in architecture. ${ }^{10}$ In the $15^{\text {th }}$ and $16^{\text {th }}$ century the occupation mason or builder (majstor, kalfa) was related to the person who helped the architect in carrying out his ideas, while in the $18^{\text {th }}$ and $19^{\text {th }}$ century the master builders were hired as the main masters and were often called upon to assume full responsibility for building houses for private clients. ${ }^{11}$

In the Ottoman Empire there was a clear differentiation of professional positions, as well as job descriptions. Consequently the highest ranked institution related to architecture was has and hassa system for recruitment and organization, with the major imperial architect on the top. A smaller group of architects was performing all the projects which were monitored by the chief has architect and referred to all important military, religious, infrastructure and strategic facilities throughout the territory of the Empire. Hierarchically, after this group of architects followed the "town architect" who was in fact an intermedium between the imperial architect and the master builders. He was nominated by the chief has architect to control all performing and constructive activities in the provincial town where important administrative, religious and public buildings were built and thus the Ottoman imperial style was imposed. ${ }^{12}$ In Ohrid, according to Evliya Çelebi, Ottoman travel writer, a town architect was entitled in the $17^{\text {th }}$ century. ${ }^{13}$ In the $18^{\text {th }}$ century, due to the increased construction activity, as a result of the economic development and increased standards of the middle class population, the town architect remained in charge only for significant objects. Residential architecture, especially buildings built for the middle class were the task of the master builders. 
Master builders originating from the territory of Macedonia have been highly respected during the Ottoman period, and as local builders they were creators of a residential architecture in Macedonia. ${ }^{14}$ Due to their mobility, they acted as agents of the process of cultural transmission and interaction on a vast geographical area which included the Ottoman Empire and beyond. The most skilful and most famous master builders came from the region of Debar and Struga, the Veles region, but also from the town of Kruševo. In the $19^{\text {th }}$ century, the guild of builders was established, which led to the formation of particular schools of building, among which those in Debar, Veles and Kriva Palanka were the most important centres of this craft. ${ }^{15}$ (Fig. 4) The basic characteristic of these schools was the strictly individualized and creative approach. They have influenced the creation of new aesthetics by bringing together architectural creativity and the applied arts - carving and fresco painting. ${ }^{16}$ The builders who came from the region of Struga were well known and respected craftsmen, especially as skilled stonecutter, plasterers and performers of delicate facades. ${ }^{17}$ The role of the famous master builders from Debar was especially appreciated and they had a special merit for the construction activities of the $19^{\text {th }}$ century all over the Balkan Peninsula. ${ }^{18}$ (Fig.4).

\section{Organization of construction work - the master builder's taifas}

The master builder guilds called taifas (tajfa) in Macedonia appear in the $17^{\text {th }}$ century. ${ }^{19}$ In general, the Balkan master builder guilds have massively appeared in the $18^{\text {th }}$ century in the western parts of the peninsula. ${ }^{20}$ With regard to their origin, these builders began their practice on rural buildings. ${ }^{21}$ Thereafter followed the training in large brigades in which they participated in the execution of important imperial buildings under the direction of trained architects. Later, the gained experience helped them to take over the full responsibility for practising design and construction on examples of secular architecture individually.

One of the reasons that led to the birth of such joint formations was probably endeavour to satisfy the existential needs of construction workers'. Skilled master builders were recruited temporarily, i.e. as needed, ${ }^{22}$ so after completion of their work obligations under the chief has architect they were free to do private work for private investors and to meet their basic needs in such a way. Another reason for joining these associations was due to the primitive technical capacities that were on their disposal..$^{23}$ They were aware that only by joining tools and physical labour they could perform difficult and complex masonry 
and carpentry works and do the construction works faster and more effectively. In this way they were able to take over the entire building and decoration work of the buildings.

In the beginning, members of the family and wider family have worked together and the craft was passed on from one generation to another. They would choose one member among themselves who would be the leader (ustabašija), and who organized and managed the affairs, discussed with the owner about the house plan, dealt with structural problems, distributed the money, but took part in the building process as well. The number of members in the guild depended on the size and complexity of the actual work. ${ }^{24}$ The nature of the construction work on large construction sites helped the creativity of the builders in the later execution of their own projects. The character and the stylistic features of the Ottoman Islamic architecture imposed the need for production of a large number of identical elements. Therefore, the master builders were asked and expected to make all the parts identically and perfectly. Consequently, talented builders who became the leading builders transmitted their creativity and gained knowledge on examples of residential architecture that they built, first in rural and then in urban houses. Other craftsmen from the guild who worked in the Empire's brigades, called saglam majstor, were highly regarded for their precision and skills in carrying out their part of the work. Apart from them, guilds also included not so talented craftsmen called the assistants (kalfa, chirak), who enabled the professional part of the team to do their job unhindered. The lowest position in the hierarchy of the crew had the children (kaldzia). Male children attended the practice within the guild and were assigned to monitor the work of a particular craftsman, gaining in this way at the very early age the knowledge through the practice and learning the techniques that were practiced by their confraternity.
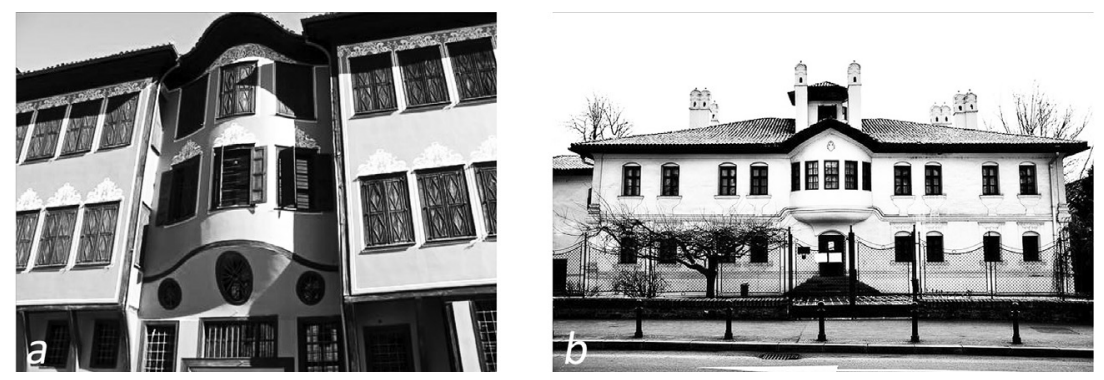

Figure 5. aroque influence on houses built by Macedonian master builders: a) House in Plovdiv; b) Konak of the Duches Ljubica - Belgrade. (source: Authors) 
The end of the $18^{\text {th }}$ century brought the division of the crafts and creation of specialized guilds for certain activities (masons and carpenters). ${ }^{25}$ Since the Ottoman house type is a combination of massive and timber-frame (bondruk) system, division of work influenced the building process and a working order of the specialized guilds. Consequently, the carpenter's guild which manufactured the ceilings, doors, windows, built-in furniture, fences, etc. came after the masons, ${ }^{26}$ while in wealthier houses, the wood-carving tajfas that manufactured the carved ceilings and even pieces of furniture, were the last.

\section{Education of the master builder}

Considering the educational level, most of the master builders were illiterate, but thanks to their openness to foreign influence (Italian in Epirus and Central European in Macedonia and Bulgaria) and to their instinctive loyalty to traditional culture, they contributed to the stylistic and linguistic unification of the building types of the Ottoman town, despite regional vernacular differences. ${ }^{27}$ However, taking into account the general degree of literacy in these areas at that time, it could be assumed that majority of craftsmen and masons were probably illiterate. On the other hand, since travelling was a part of their work, they were exposed to numerous influences that have formed and built their intellect foreign languages, the influences of different cultures and the current European and Empire's trends in architecture, which could be understood as a type of education.

Master builders did not use technical drawings before the $19^{\text {th }}$ century, which is quite understandable since prior to the $17^{\text {th }}$ century there were no technical drawings in the entire Ottoman Empire, not even for the significant architectural buildings. ${ }^{28}$ Instead of technical drawings, builders from Macedonia, northern Greece and Bulgaria often used a rope for marking their plans directly on the site, which sometimes offered a much better performance: harmonious proportions, golden section, etc.

It could be assumed that within the taifas, builders were learning from the head masters, orally and empirically. The plastic and exciting forms that were created (Fig.3) were more a result of an experiment or subtle structural, logical and aesthetic sense of the master builder. Free from any theoretical architectural guidance, they studied the architectural styles from the examples of the built structures in the towns in which they worked. The master builders are responsible for coming up with some innovative solutions that resulted from adapting the current European styles by using traditional construction techniques. There was 
a practice of transposing certain innovative architectural solutions to other parts of the Empire. ${ }^{29}$ With respect to this, the stylistic and structural modification and the symbiosis of the Baroque European influences and the Ottoman architecture typical for Ohrid Christian houses, continued to pass on and develop within the urban nucleus of the Empire (Fig. 5). ${ }^{30}$

\section{Importance of construction contracts}

Preserved archive material reveals that, when a church was constructed, drawing plans were an essential part of the master builder's job. However, this was much less practiced in the construction of the residential buildings. Certain authors believe that only in the $19^{\text {th }}$ century some buildings (houses of rich owners and other important buildings) were built according to the plans and which were very scarce with information. Therefore, the construction contracts had an important role in defining the project and supporting documents. A contract was signed between the investors and the leaders of the guilds, specifying the basic information about the building itself and the process of its erection, as well as the obligations for both parties. ${ }^{31}$ This document, other than the legal content, explains the details of construction of the building. Contracts often defined the length and width of the object, the presence of consoles, the width and the height of the frontal wall of the foundation, number of stories in the house and their clean height, number, dimensions and disposition of built-in windows and doors on each floor separately, description of the chimney. The contract also specified who provided the material, the method of making the façade, payment instructions for the agreed sum, the deadline of the construction, etc. ${ }^{32}$ Since the socio-political situation, particularly in the $19^{\text {th }}$ century was unstable, it influenced the use and the role of the contract, which, on one side, ensured guarantees for the payment and the work on the other.

The measures in the contracts and the plans were most often expressed using the yardstick measure system. The yardstick ( $\operatorname{arssin}$ ) measurement system represents a small part of a large group of anthropomorphic measures, which originated at the time of territorial and political expansion of the Islamic world and became the official measure of the Ottoman Empire. ${ }^{33}$ In order to avoid arbitrariness in the measurement process, there were several types of yardsticks that were used in the Empire for the trade, supervised by the authorities. ${ }^{34}$ Typical for the town of Ohrid was the use of two types of yardsticks, one called a construction yardstick (zirai mimari) which measured $75-76 \mathrm{~cm}$, and another one called an artisan yardstick (endeze zirai), which measured $60-64 \mathrm{~cm}$. The yardstick system was implemented in all areas of construction: masonry, carpentry, 
delicate crafts in the preparation of the wooden engravings, etc. The arşin was both a tool and a module, which resulted in a system easily adaptable both to construction techniques and to the spatial conception of the buildings.

Official introduction of the metric system happened in the Empire in the second half of the 19th century. However, it was hardly accepted. None of the prescribed legal provisions was able to restrict the use of the yardstick, which was the widespread measure that remained in use for a long, especially among the Macedonian population. Later in the 19th century in the contracts, the dimensions of the building (width/height), height of the floor and the width of the consoles were expressed in yardsticks, while the built-in furniture, doors and windows were expressed using the metric system. The dimensions that were expressed in centimetres were basically pieces, whole or repetitive amount of yardsticks. The plans were usually measured in yardsticks, although there were examples of plans with simultaneous use of both, yardstick and metric systems. This indicates that the master builders continued to measure and to perform a proportional ratio between the vertical and the horizontal plan using the yardstick which was afterwards converted into the metric measurement system.

\section{WORK AND CREATIVE ARCHITECTURAL CONTRIBUTION OF MASTER BUILDERS IN OHRID}

Closeness of important building schools of Debar and Struga to the town of Ohrid contributed to the fact that most builders from this region were working on the territory of Ohrid, which explains the good quality of craft works of local architecture. They were traditionally invited to Ohrid whenever there was a need for construction of important and representative buildings. ${ }^{35}$ Not only builders, but also the famous carving guilds from Debar, as well as local guilds from Ohrid itself worked on the territory of Ohrid. ${ }^{36}$ In $19^{\text {th }}$ century the Ohrid carving school became very appreciated and influential. Even today the woodcarving craft is still nourished in Ohrid.

It can be said that the master builders of the Debar school set a higher level of performance in the construction and equipment of residential buildings in the town of Ohrid. Local - Ohrid and Struga master builders used the knowledge of the Debar school, but they were also learning from examples of the past traditions from their immediate surroundings and from parts of the Empire where they worked. ${ }^{37}$ 


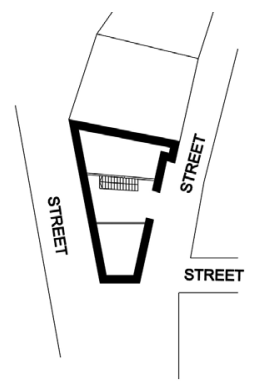

1. THE STONE WALL FOLLOWS THE PLOT LINE OF THE PARCEL

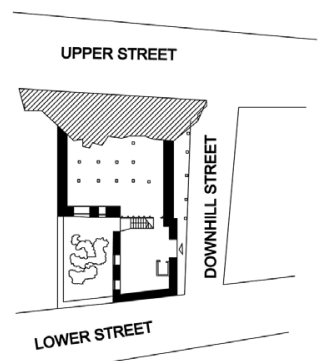

2. THE BUILDING LEANING ON THE ROCK



3. ENTRENCHING THE BUILDING IN THE GROUND

Figure 6. Alternative solutions in resolving problems of small and / or rocky locations (source: Authors)
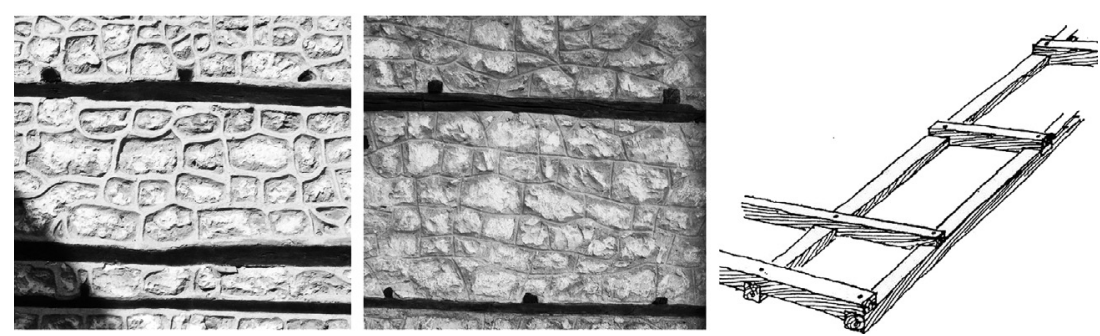

Figure 7. Type of finishings and stiffening of stone walls: a) Concaved mortar joints and visible cerclages; b) Convexed mortar joints and visible cerclage; c) A system of wooden cerclages (santrač). (source: Чипан, Б. Старата градска архитектура во Охрид. Скопје: Македонска книга, 1982.)
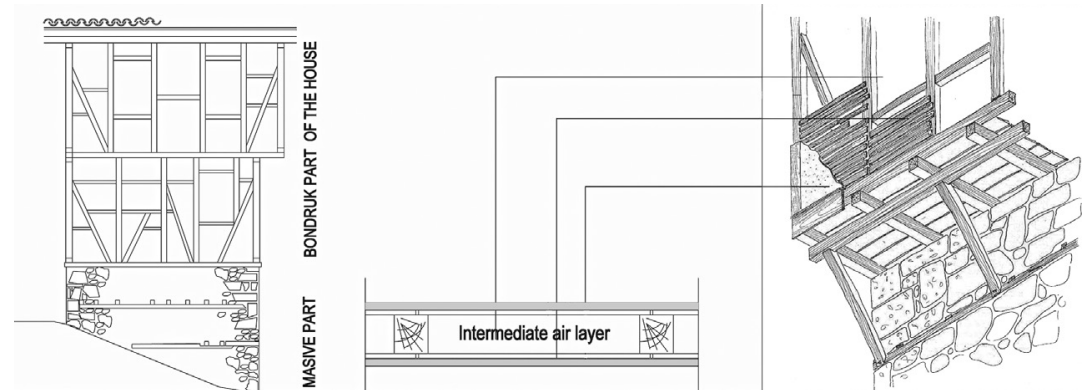

Figure 8. Structural system of a traditional Ohrid house (source: Authors) 

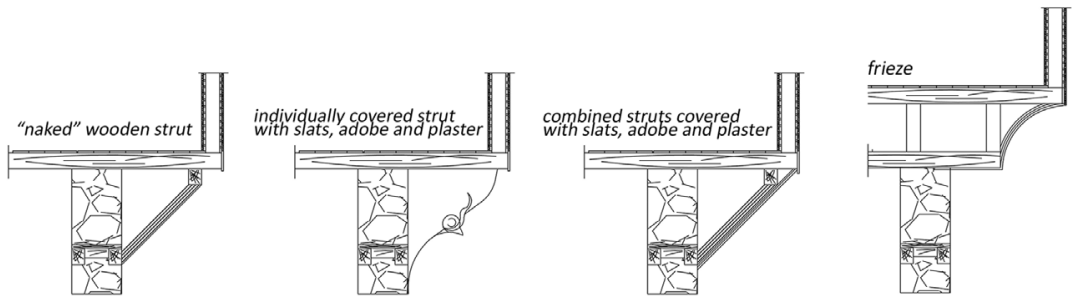

Figure 9. Variations in construction of consoles (source: Authors)

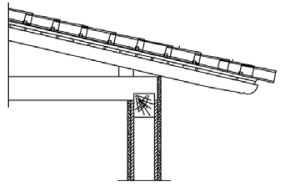

eave with a
visible construction

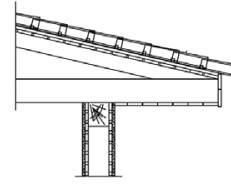
eave covered with
wooden planks

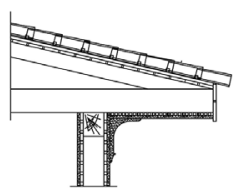
eave coated with
wooden planks and plaster

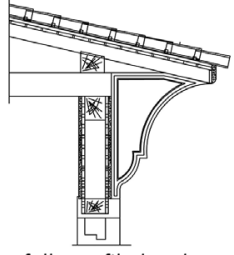

fully profiled and
exposed frieze

Figure 10. Typical examples of the eaves (source: Authors)

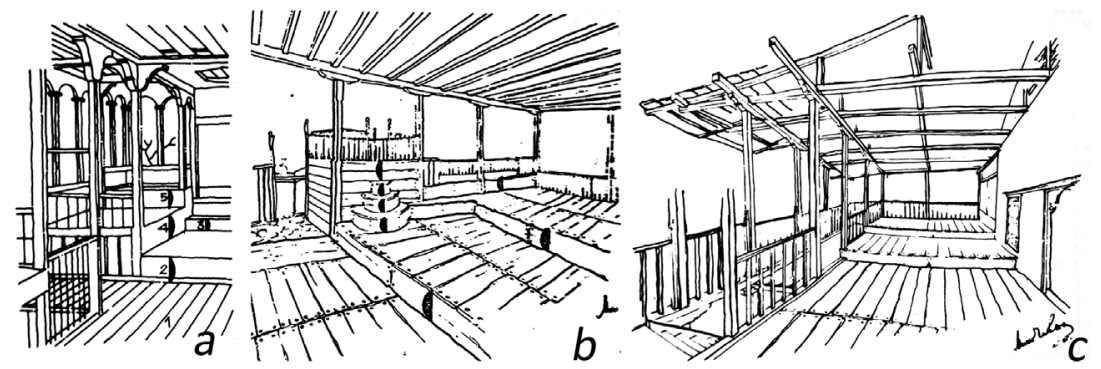

Figure 11. Multi-level floor of the balcony (čardak): a) Debar house; b) Muslim house in Ohrid; c) Christian house in Ohrid. (source: Хаџиева Алексиевска, Мерки, Антропоморфност и модуларни пропориии кај старата македонска куќа, Скопје: Студентски збор, 1985.) 
Construction of traditional residential houses in Ohrid was accompanied by specific challenges that had to be solved by the builder. In a situation where the construction site offered minimum opportunities and the needs of the everyday life were huge, the master's knowledge of structural problems played the key role in solving the problems with narrow locations on rocky sites. Due to different shapes and sizes of lots, as well as requirements of investors, there was not a unique solution of the problem. Therefore, the position of the building on the limited area that was on disposal might have been resolved in specific ways: so that the stone wall followed the line of the parcel, or the foundation of the building was done directly on the rock, or the building was dug into the soil. (Fig.6) The walls were built of irregular stone blocks that were usually found on the site and were bonded either with mud or rarely with lime mortar. They were properly stiffened and levelled with a system of wooden beams or wooden cerclages called santrač that might be visible on the façade. The stone walls of Ohrid houses were not necessarily plastered, but the joints were professionally constructed in several ways: they were concave or convex (Fig.7), sometimes painted in white paint, which created an exciting texture. Specific construction of this wall provided a unique appearance, while it saved energy in the processing of the stone material at the same time. ${ }^{38}$ However, one must note that besides the fact that material and energy conservation strategies were applied; the aesthetical qualities of the wall were not lost. On the contrary, they reinforced an authentic expression of this regional architecture.

Upper parts of traditional Ohrid houses were constructed in timber-frame (bondruk) structure. Although the structural concept of a bondruk system was a common feature in all the regions of the Empire, the infill of such walls might have varied, depending on the climate and availability of resources. In this sense, one of the peculiarities of the Ohrid house was the timber-frame (bondruk) wall itself - $18 \mathrm{~cm}$ thick wall, which is a combination of two layers of wooden cladding and an intermediate air layer (Fig.8), which resulted in creation of a a very light construction that was a typical solution not only for Ohrid, but also for some other towns in the Ottoman Empire. ${ }^{39}$ In a search for a better solution of external cover of a bondruk wall that would provide better resistance to the effects of the strong south wind in Ohrid and better bonding with wooden planks, master builders applied a tin cover. ${ }^{40}$ This was not a good solution, but it indicated a process of experimentation and occurrence of certain solutions. In the final stage, builders used wooden, dark patina stitches, which were installed in critical areas, having a functional and aesthetic role as well. ${ }^{41}$ The large number of storeys, typical for traditional Ohrid houses, was a result of the master builders' sufficient knowledge in statics and awareness of potentials of a timber-frame (bondruk) structure. 
The timber-frame (bondruk) system allows that a part or the whole length of the floor hangs over the regulatory line of the ground floor. In this way, the usually irregular shape of the ground floor plan of Ohrid houses might have been transformed into a proper form in the upper floors, increasing at the same time the floor plan. Overhangs that were called erker might have had different shapes as a result of the specific problems and requirements, such as rectangular shape which was the most performed shape, semi-circular or segmental shape that was rarely present in Ohrid but which represents an influence of the Debar school, the same as polygonal shape. Triangular or trapezoidal shapes were also present as a direct result of the correction of the irregular base of the ground floor of the house. Structurally, there were several variations and ways of performing consoles (Fig. 9). Although it was not necessary, the beams could be supported with struts that might have been "naked" wooden struts (the oldest form of struts), individually covered with slats, adobe and plaster, or covered in the same way all together. Basically, application of struts was a structural need. However, in the second half of the $19^{\text {th }}$ century, as a result of the investors' desire to have a house in a European-fashion style, struts were covered as described, pointing out the aesthetic sensibility of a master builder.

The roof construction was very uneconomical, with a gentle sloping of the eaves on all four sides. ${ }^{42}$ The builder paid the most attention to the final modelling of the roof as a part of a complete volume of the composition of the house and the modelling of the eaves (Fig.10), which is a mostly visible part of the roof seen from the street (Fig.3). The most exciting roof solutions are seen on the example of Ohrid houses from the second half of the $19^{\text {th }}$ century. Some of these roofs created a very interesting silhouette of the house. Usually, the two or four hipped roofs were transformed into semi-circular and segmented shapes. On the front façade, the semi-circular and arched tympanums clearly emphasized the new fusion between the Oriental and western European styles. These solutions were usually adaptations and modifications of the Baroque style, derived in timber-frame construction.

Typical spatial solution of Ohrid houses were levelled floors. This feature was an influence of the Debar school which master builders from Ohrid developed to the highest level (Fig.11). While in the Debar house such floor was present only in the balcony, in the Ohrid house there were examples with different heights of the rooms on the same floor. ${ }^{43}$ The desire of the investors for exposing towards the exterior and the urban life resulted in a superposition of several levels into an exciting dynamic composition, especially in the open balcony (Fig.11). The finalization of the floor is treated minimalistic: with no carved details, allowing the viewer to enjoy the play of the volumes. 


\section{CONCLUSION}

The emergence and development of the traditional Ohrid house, as a regional variant of the Ottoman type of urban house with specific indigenous characteristics that are specifically related to the spatial plan and the structural details, was created by Ohrid, Struga and Debar master builders. The creation and implementation of certain elements in most cases was a result of the master builders approach in resolving the constructive and design problems, which was based on taking over certain methods of construction, architectural elements and structural detailing of the past and the current styles, their adaptation in the applied structural system and with the materials that were used, and modification of the elements of construction and finalization to the climate and the plot, as well as the aesthetic criteria of the population.

The presence and work of the Debar master builders is considered to be meritorious for adaptation of the rural type of house from Galičnik and the universal Ottoman type, according to the specific conditions of climate and topographic feature of the town, as well as the cultural habits of the Christian population of Ohrid, which resulted in creation of the Ohrid house. Their practice on the territory of Ohrid has raised the quality of the residential architecture on a higher level. The prevalence of certain architectural forms (semi-circular and polygonal forms of the consoles), as well as of certain elements of the finalization (the carved ceilings, the multi-levelled floors) was influenced by the Debar school. However, although master builders from Ohrid and Struga learned from the work of Debar master builders, they also relied on the architectural examples of the past traditions from their immediate surroundings.

On the other hand, mobility of the master builders and their work abroad exposed them to the Western European influence which they have modified and adapted together with the Ottoman influence that they have incorporated in their own way.

The master builder can be characterized as an intelligent creator who feels and understands the nature, the local materials and who uses his intuitive approach to come up with architectural solutions of high quality. Analysing the different construction techniques, he selectively accepted and further developed some construction techniques, architectural elements and structural details, which belonged to previous eras, as well as to other cultures of the broader region. Through a long process of experimentation and analyses of the habits and desires of the Christian population, the master builder was able to produce a specific architectural expression of their houses, which differs both from the Muslim houses built in Ohrid, as well as the houses in other areas in Macedonia or broader, resulting with a creation of the traditional Ohrid house. 
D. Kuban, The Turkish Hayat House (Istambul: 1993), 47.

A. Дероко, Народно неимарство II (Београд: Српска академија наука и уметности, Одељење друштвених наука, 1968), 4-10; А. Дероко, Фолклорна архитектура у Југославији (Београд: Научна књига, 1964), 7.

Ј. Хаџиева Алексиевска, Мерки, Антропоморфност и модуларни пропорции кај старата македонска куќ (Скопје: Студентски збор, 1985), 14.

С. Томоски, Македонска народна архитектура (Скопје: Технички Факултет - Скопје, Институт за народна архитектура), 5 .

М. Николоска, “"Просторна организаиија градске куће XIX века у Македонији” (Докторска дисертације, Београд: Архитектонски Факултет, Универзитет у Београду, 2000). [Space organization of the urban houses from the 19th century in Macedonia - PhD thesis, Belgrade, Faculty of architecture], 219. Ibid, 134

E. Čelebija, Putopis, odlomci o jugoslovenskim zemljama, vol. II. (Sarajevo: Svjetlost, 1957), 110. This statement was claimed by many authors who explore the Macedonian traditional house, and the Ohrid house accordingly, such as: Boris Chipan, Krum Tomovski, Sotir Tomoski, Jasmina Hadžieva Aleksievska.

In the $17^{\text {th }}$ century in his description, Čelebija speaks of a clear division of the city in Upper City (with 160 Christian houses), Lower City (with 17 neighbourhoods: 10 Muslim and 7 Christian) and the bazaar. Čelebija, Putopis, odlomci o jugoslovenskim zemljama, 107-110.

Ibid., 88.

Ibid., 88.

Čelebija, Putopis, odlomci o jugoslovenskim zemljama, 110.

К. Хаџиева Алексиевска, Македонските мајстори градители од XIX ве. (Скопје: МАНУ, 2006), 15.

The master builders that came from these schools were highly respected and appreciated in the Balkan countries and have worked in: Bulgaria, Serbia, Montenegro, Bosnia and Herzegovina, Dalmatia, Albania, Romania, Greece, as well as in the broader region: Anatolia, Austria-Hungary and Egypt. J., Хаџиева Алексиевска,“Македонските градители, градителски школи и нивната улога во создавањето на новата архитектонска естетика во преродбенската сакрална архитектура,” in Историја на културата на Македонија: Содржински и методолошки прашања (Скопје: Макопроект: „Историја на културата на Македонија“, book 9, МАНУ, 1999), 131.

Томовски, Македонските мајстори градители, 9.

There is a proverb, which, according to many authors, is probably a result of these facts, which goes: "If Istanbul falls apart, Debar will build it again, but if Debar falls apart, even Istanbul would not be able to rebuild it." Ibid, 9.

Хаџиева Алексиевска,“Македонските градители, градителски школи ”, 131.

M., Cerasi, "Late-Ottoman Architects and Master Builders," Muqarnas, Vol.5 (1988)“: 89-90.

Most of the Macedonian builders were born in the villages, especially those from the Debar region. This region is consists of many mountain vilages located in areas around the town of Debar: the Galičnik-Reka region, Debar valley, parish of Župa, Drimkol of Debar and Golo Brdo.

The organization and division of the labour on the large construction sites in the Empire, was predetermined and used since the $16^{\text {th }}$ century. There were three groups of participants: 1 ) a small group of architects (designers and constructors); 2) a large number of administrative staff (led by administrative and financial supervisors), and 3) the master builders. Skilled labour was recruited temporarily, i.e. as needed and only for a certain period. Cerasi, "Late-Ottoman Architects and Master Builders, ", 92. 
М., Цепенков, Материјали и литературни творби. book 10, 1829, edited: Б. Ристовски (Скопје: Институт за фолклор, Импресум: Македонска книга, 1972), 61; Мерки Хаџиева Алексиевска, Антропоморфност и модуларни пропорици, 61.

Мерки Хаџиева Алексиевска, Антропоморфност и модуларни пропорции, 77-79.

Хаџиева Алексиевска,“Македонските градители, градителски школи”, 130. Ibid, 130.

Cerasi, “Late-Ottoman Architects and Master Builders," 94-97.

Cerasi explains that before the twelfth century there weren't any technical drawings even in the most important archive of Topkapi. These drawings were made later, under the stronger European influence. Ibid, p. 93.

Ibid, 89.

This can be seen on examples of some urban houses in Bulgaria - particularly the houses from Plovdiv. These solutions were passed on by the Macedonian master builders and later were even more developed by other master builders in the other parts of the Empire (for example: the Palace of Duchess Ljubica and the Ivko's House in Belgrade, Serbia).

В. Гиновски, “Договори за дело и организација на работата во практиката на зидарските тајфи во Западна Македонија во XIX и почеток на XX век“, Старата селска архитектура: Заштита и ревитализација (материјали из симпозијума “Дебар - манастир Јован Бигорски“ - Галичник, Скопје: Архитектонски Факултет, 1972, 100-102). Unknown autor, [Contract: Kontrakt za Liri 105. ]. 1905, the document is a private property of the Ginovski family, State arhive (fotocopy of the original), inv. br. 27/ c40, Skopje. The yardstick (arşin) is an anthropomorphic measure, with a length determined by the distance from the shoulder joint to the end of the middle finger of the outstretched hand. Д. Пљаковски, Модуларната координација како ефикасен инструмент sа дименsионална ускладеност на елементите во индустриското проияводство ( Скопје: Архитектонски факултет, 1977), 8. It's important to mention the famous ustabašija Todor Petkov from the Debar region, who together with his crew built the famous house of the Robevci family in Ohrid. A great number of houses of the Ohrid rulers (beg, čorbadžija) were built under his leadership. In the decoration of the interior of the Robevci house, Dico Zograf - one of the most famous carvers from Debar carving school, also took part. М. Шерденковска, „Градителската дејност на мијаците,” Културно наследство, Скопје: Културно наследство, o. 30-31 (2004-2005): 189. The wood carving craft in the interior of the secular architecture in Macedonia is practiced from the $18^{\text {th }}$ century. The wood-carving crews from the Debar region were working on Athos, where they improved their craft. Д. Корнаков, “Македонска средновековна резба.”, Историјата на културата на Македонија, Макопроект: Историја на културата на Македонија. Book 9. (Скопје: МАНУ, 1999), 109 - 118.

Б. Којић, Стара градска и сеоска архитектура у Србији ( Београд: Просвета, 1949), 60. Tutors of Catedral church in Sarajevo to Andrea Damjanov, [letter], 7 Februar 1867, Sarajevo, Name of collection: „Korespodencija - Damjanovi“, State Archive of R. Macedonia, Skopje. If the stone was processed, a huge amount of this material would have been wasted, in order to achieve symmetrical and regularly shaped stone blocks. Furthermore, if the overall surface of the stone wall was plastered, a considerable additional amount of plaster would have been needed. In addition to save the material, this principle saved human resources and shortened the time needed for constructing the massive part of the house.

This type of a bondruk wall was also used in Siatista, Kastoria, Sliven, as well as some towns in Anadolia. See: D. Ve-I-Kou, Nomikou-Rizou D. Siatista, Greek Traditional architecture (Athens: 1990), 32, 36; K.N. Moutsopoulos, Kastoria, Greek Traditional architecture (Athens, 1990), 33, 51; Р. Ангелова, Сливен и неговата архитектура преs взбражденето (Софија, 1969), 73-74; G. Arun, Traditional Timber Structures in Turkey, Structural Analysis of Historical Constructions - Jerzy Jasienko (ed), DWE (Wroctlaw, Poland: 2012), 1000-1001. 
Certain parts of the bondruk walls, such as the vertical poles at the corners, the beams between the windows and the sides of the floor construction, where the plaster binds more difficult, were covered with wooden planks. карактеристичне нијансе израза народне архитектура Македоније”, Зборник радова Архитектонског факултета (Београд: Архитектонски Факултет, 1951-52), 78.

Николоска, “'Просторна организаичја градске куће ХІХ века у Македонији’, 213.

Ангелова, Рашела. Сливен и неговата архитектура през взбражденето. Софија, 1969.

Arun, Görün. Traditional Timber Structures in Turkey, in: Structural Analysis of Historical Constructions, Jerzy Jasienko (ed), DWE, Wroctlaw, Poland, 2012, 995-1002.

Cerasi, Maurice. "Late-Ottoman Architects and Master Builders", Muqarnas, Vol.5 (1988), 87-102. Цепенков, Марко Материјали и литературни творби. book 10 (1829), edited: Б. Ристовски, Скопје: Институт за фолклор, Импресум: Македонска книга, 1972.

Дероко, Александар. Народно неимарство II. Београд: Српска академија наука и уметности, Одељење друштвених наука, 1968.

Дероко, Александар. Народна архитектура II: Фолклорна архитектура у Југославији. Београд: Научна књига, 1964.

Гиновски, Владимир. “Договори за дело и организација на работата во практиката на зидарските тајфи во Западна Македонија во XIX и почеток на XX век“. Cтарата селска архитектура: Заштита и ревитализаџија, материјали из симпозијума "Дебар манастир Јован Бигорски “ - Галичник. Скопје: Архитектонски Факултет, 1972, 100-108.

Хаџиева Алексиевска, Јасмина. Мерки, Антропоморфност и модуларни пропорции кај старата македонска куќа. Скопје: Студентски збор, 1985. 
Хаџиева Алексиевска, Јасмина. “Македонските градители, градителски школи и нивната улога во создавањето на новата архитектонска естетика во преродбенската сакрална архитектура”, in: Историја на културата на Македонија: Содржински и методолошки прашања. Скопје: Макопроект: „Историја на културата на Македонија“, book 9, МАНУ, 1999, 129-135.

Којић, Бранислав. Стара градска и сеоска архитектура у Србији, Београд: Просвета, 1949.

Крунић, Јован. „Облици народних кућа Охрида, Киченице, Галичника и Крушева као карактеристичне нијансе израза народне архитектура Македоније". Зборник радова Архитектонског факултета. Београд: Архитектонски Факултет, 1951-52, 64-78.

Kuban, Doğan The Turkish Hayat House, Istanbul, 1993.

Moutsopoulos, N. Konstadinos (1990). Kastoria, Greek Traditional architecture, Athens.

Николоска, Марула. Просторна организаиија градске куће XIX века у Македонији. Београд: Архитектонски Факултет, Универзитет у Београду [Space organization of the urban houses from the 19th century in Macedonia - PhD thesis, Belgrade, Faculty of architecture], 2000.

Пљаковски, Драган. Модуларната координаиија како ефикасен инструмент ма димензионална ускладеност на елементите во индустриското производство. Скопје: Архитектонски факултет, 1977.

Томовски, Крум. Македонските мајстори градители од XIX век. Скопје: МАНУ, 2006.

Томоски, Сотир. Македонска народна архитектура. Скопје: Технички Факултет - Скопје, Институт за народна архитектура, 1960.

Tutors of Catedral church in Sarajevo to Andrea Damjanov, [letter], 7 Februar 1867, Sarajevo, Name of collection: „Korespodencija - Damjanovi“, State Archive of R. Macedonia, Skopje.

Unknown autor, [Contract: Kontrakt za Liri 105. ]. 1905, the document is a private property of the Ginovski family, State arhive (fotocopy of the original), inv. br. 27/ c40, Skopje.

Veikou, Despeina, Nomikou-Rizou, Danae. Siatista, Greek Traditional architecture. Athens: Library of art, 1990.

Čelebija, Evlija. Putopis, odlomci o jugoslovenskim zemljama, vol. II. Sarajevo: Svjetlost, 1957.

Ќорнаков, Драган. “Македонска средновековна резба”, in: Историјата на културата на Македонија, Макопроект: Историја на културата на Македонија, book 9. Скопје: МАНУ, 1999, 109-118.

Шерденковска, Меланија. „Градителската дејност на мијаците”, in: Културно наследство. Скопје: Културно наследство, №. 30-31(2004-2005), 187-196. 